\title{
STANDAARD \\ VERPLEEGVOORSKRIFTE \\ VIR VOORGEBOORTE KLIËNTE
}

\section{SYLVIA VENTER EN PAULA DU PLOOY}

\section{SUMMARY}

Inspired after attending the course in scientific education for the nursing process, given by Mrs I.M. Miles at the J.G. Strijdom Hospital in February 1984, this standard nursing care plan for antenatal clients was born.

It is based on the nursing module.
Sylvia Venter, BA(Verpl), (PU vir CHO), MCur (Verloskundige Verpleegkunde, GAV, GVV, GPV. CHN, V.Ond., VAdmin. Lektrise, Departement Verpleegkunde, PU vir CHO.

Paula du Plooy, GAV, GVV, Senior Verpleegkundige, Verloskunde Afdeling, Klerksdorp Provinsiale Hospitaal.

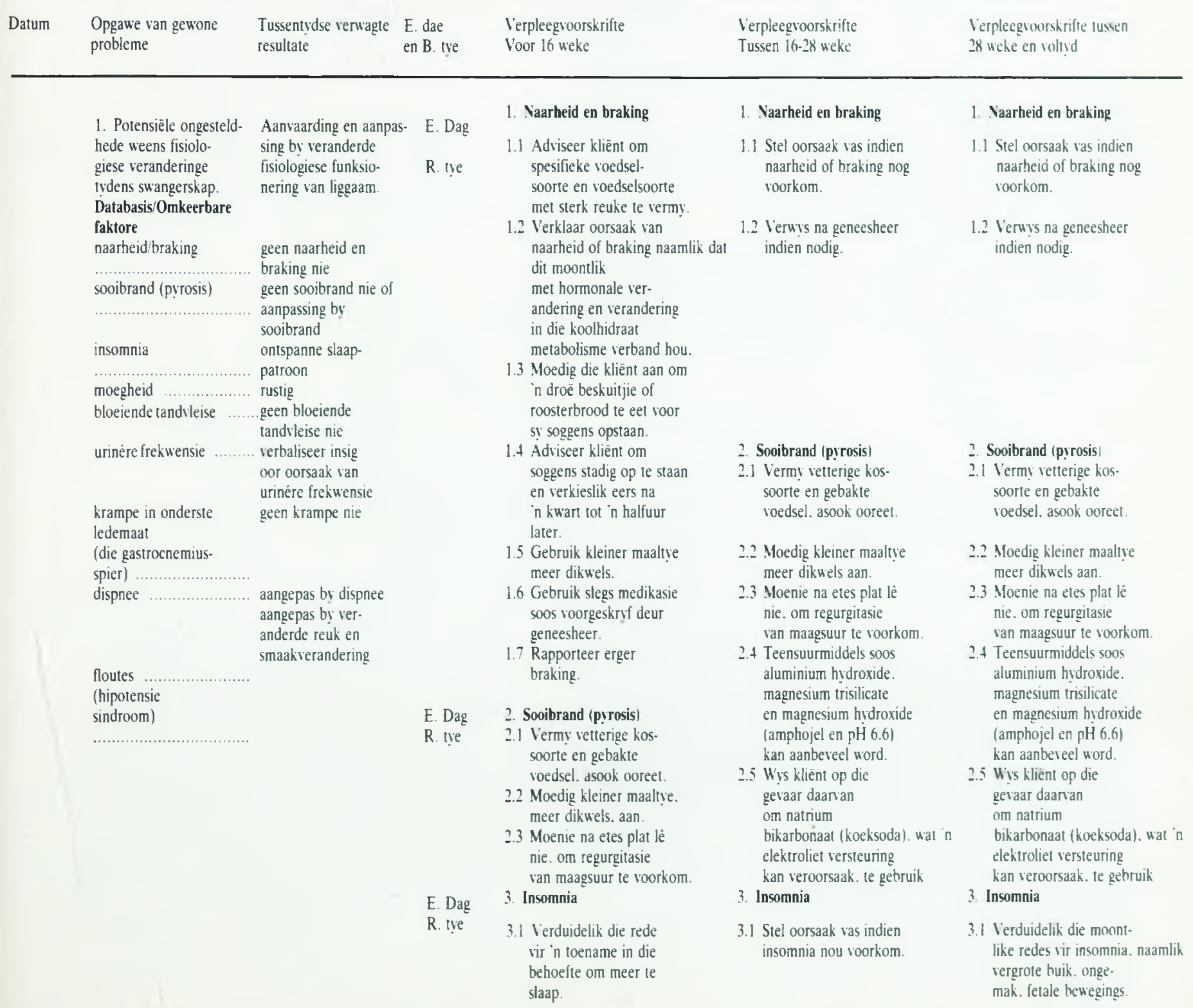


Verpleegvoorskrifte

Voor 16 wek

3.2 Moedig addisionele rustye deur die dag an

3.3 Beraam 'n realistiese plan vir kort rusperiodes en ontspanning wat by die kliënt se daaglikse skedule aanpas.

3.4 Moedig oefeninge aan wat by kliënt se lewenstyl aanpas, soos loop.

3.5 Demonstreer in ontspanningstegniek aan kliënt. byvoor beeld. ' $n$ geleidelike kontraksie en ontspanning van alle spiergroepe vanaf die voete tot by die top van die kop.

4. Moegheid

4.1 Stel oorsaak van moegheid vas en probeer 'n plan van aksie om aktiwiteite te beperk voorstel.

4.2 Verduidelik die effek van verhoogde progesteroon aan die kliënt.

4.3 Kontroleer of kliënt voorgeskrewe ysterpreparate neem indien naarheid en braking nie meer voorkom nie.

4.4 Kontroleer dieetinname.

5. Bloeiende tandvleise

5.1 Stel vas of kliënt al by 'n tandarts was.

5.2 Verwys kliënt na tandarts vir profilaktiese behandeling

5.3 Stel die gebruik van 'n tandepasta vir sensiticwe tandvleis, soos Sensidine, voor

5.4 Kontroleer dieet vir Vit. C inname en gee advies

6. Urinêre frekwensie

6.1 Verduidelik oorsaak aan kliënt, naamlik dat dit die vergrote uterus is wat op die blaas druk.

6.2 Daar is geen metode om frekwensie van urine teë te werk nie.

6.3 Beklemtoon die belangrikheid om nooit die vjoeistofinname te beperk nie

6.4 Bevorder goeie perineale spiertonus deur die kliënt te leer om die pubokoksigieuse spier saam te trek (Kegel se oefening).

6.5 Skakel urinêreweginfeksie uit. Doen in mikroskopiese ontleding. Verwys na geneesheer

6.6 Indien 6.5 teenwoordig is, moedig 3-4 liter vloeistofinname per dag aan.

\section{Moegheid}

4.1 Stel oorsaak van moegheid vas en probeer in plan van aksie om aktiwiteite te beperk voorstel

4.2 Verduidelik die effek van verhoogde progesteroon aan die kliënt.

43 Kontroleer of kliënt voorgeskrewe ysterpreparate neem.

4.4 Kontroleer dieetinname 5. Bloeiende tandvleise

5.1 Stel vas of kliënt a by 'n tandarts was.

5.2 Verwys kliënt na tandarts vir profilaktiese behandeling.

5.3 Stel die gebruik van in tandepasta vir sensitiewe tandvleis. Soos Sensidine. voor.

\section{Urinêre frekwensie}

6.1 Stel oorsaak vas en verwys na 'n geneesheer.

6.2 Bevorder steeds goeje spiertonus deur die kliënt te leer om die pubokoksigieuse spier saam te trek (Kegel se oefening).

6.3 Beklemtoon die belang rikheid om nooit die vloeistofinname te beperk nie.

6.4 Skakel urinêreweginfeksie uit. Doen in mikroskopiese ontleding Verwys na geneesheer.

6.5 Indien 6.4 teenwoordig is moedig 3-4 lite vloeistofinname per dag aan.

6.6 Verduidelik die gebruiks aanwysings van medikasie
4. Moegheid

4.1 Stel oorsaak van moegheid vas en probeer in plan van aksie om aktiwiteite te beperk voorstel.

4.2 Verduidelik die effek van verhoogde progesteroon aan die kliënt.

4.3 Kontroleer of kliën voorgeskrewe ysterpreparate neem

4.4 Kontroleer dieetinname 5. Bloeiende tandvleise

5.1 Stel vas of kliënt al by 'n tandarts was.

5.2 Verwys kliënt na tandarts vir profilaktiese behandeling.

5.3 Stel die gebruik van "n tandepasta vir sensitiewe tandvleis. Soos Sensidine, voor

\section{Urinêre frekwensie}

6.1 Verduidelik oorsaak aan kliënt, naamlik dat dit die vergrote uterus is wat op die blaas druk

6.2 Daar is geen metode om frekwensie van urine teë te werk nie.

6.3 Beklemtoon die belang rikheid om nooit die vloeistofinname tc beperk nie.

6.4 Bevorder goeie perineale spiertonus deu die kliënt te leer om die pubokoksigieuse spier saam te trek (Kegel se oefening)

6.5. Verduidelik dat selifs hoes o nies lekkasie van urine in die laaste maand van swangerskap kan teweegbring

6.6 Skakel urinêreweginfeksie uit. Doen in mikroskopiese ontleding Verwys na geneesheer.

6.7 Indien 6.6 teenwoordig is moedig 3-4 liter vloeistofinname per dag aan. Verduidelik die gebruiksaanwysings van medikasie. 
Datum Opgawe van gewone probleme
Tussentydse verwagte resultate

\section{E. dae Verpleegvoorskrifte \\ en B. tye \\ E. Dag \\ R. tye \\ Voor 16 weke \\ 7. Krampe in onderste spier \\ 7.1 Waarsku kliënt om nie distensie van voete te doen wanneer sy voorge- boorte oefeninge doen as sy geneig is om krampe te kry nie.}

7.2 As krampe voorkom plaas voete in dorsifleksie. Massering en aanwending van hitte kan dit verlig.

7.3 Gebruik medikasie soos roorgeskryf.

\section{7.f Moet nie melk totaal uit die dieet uitskake nie omdat dit noodsaak. like nutriènte bevat.}

E. Dag
R. tye

\section{Dispnee}

8.1 Stel oorsaak vas en verw's na in genees beer.

\section{E. Dag 9. Floutes}

R. tve

9.1 Verduidelik oorsaak van floutes aan die kliënt. naamlik dat dit in kombinasie van die verandering in haar bloedvolume is asook posturale hipotensie wat die bloed in die afhanklike bloedvate laat ophoop. Skielike posisieverandennge kan dit aanbring.

9.2 Voorkom lang staan in in warm. oorberolkte kamer.

9.3 Sit met kop tussen bene.

9.4 Indien laasgenoemde nie help nie. soek in plek waar sy plat kan lé en stıwe klere kan losmaak.

9.5 Wanneer kliënt dan op staan. moet dit stadig geskied.

9.1 Stel oorsaak vas en veruys na in geneesheer.
}

\subsection{Moet nie melk totaal uit die dieet uitskake nie omdat dit noodsaak - like nutriënte bevat.}

7.2 As krampe voorkom plaas voete in dorsifleksie.

Massering en aan-

7.3 Gebruik medikasie soos roorgeskryf

\section{Dispnee}

8.1 Stel oorsaak vas en verwys na in geneesheer
Verpleegvoorskrifte tussen 28 weke en voltyd

7. Beenkrampe

7.1 Verduidelik oorsaak. naamlik dat die vergrote uterus druk uitoefen op die senuwee wat die laer ekstremiteit voorsien. asook dat suak sirkulasie en moegheid dit kan bevorder.

7.2 Lig voetenend san die bed om bloedsirkulasie te verbeter

7.3 Beperk melkinname na 'n liter of minder per dag en verduidelik

dat die hoë fosforvlakke in bloed die kalsium onderdruk

7.4 Gebruik medikasie soos deur geneesheer voorgeskrvf bv. aluminium hrdroxide gel wat die serking van fosfor op kalsium stop.

7.5 Gebruik medikasic soos deur geneesheer rorgesknif vir addisionele kalsium toediening.

7.6 As krampe rookkom plaas voete in dorsifleksie met die knie plat op die bed. met die hulp san "n tweede persoon.

7.7 Waarsku kliënt om nie distensie van voete te doen uanneer sy vorgeboorte oefeninge doen as sy geneig is om krampe te kry nie.

8. Dispnee

8.1 Word bedags verlig deur regop in "is stoel te sit en deur in goeie houding wanneer staan

8.2 Snags word dit verlig deur "n paar kussings onder die kop en skouers te plaas.

8.3 Verduidelik oorsaak aan die kliënt. en aan die multipara dat dit moontlik eers in baring kan verlig omdat indaling by hulle so laat plaasvind.

9. Floutes 9. Floutes

9.1 Stel oorsaak vas en venwis na in geneesheer 


\section{Hipotensie Sindroom}

10.1 Verduidelik oorsaak aan kliënt.

10.2 Draai op linkersy

\begin{tabular}{|c|c|}
\hline 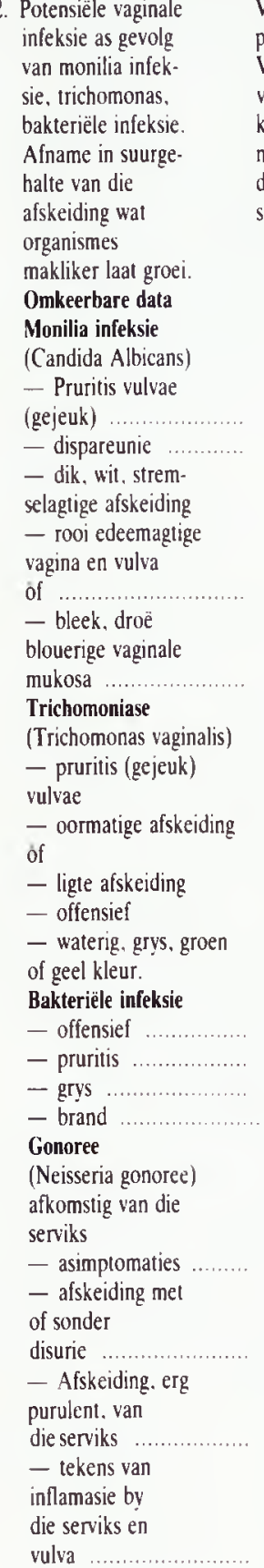 & $\begin{array}{l}\text { Vel pienk of donker } \\
\text { pienk in kleur. } \\
\text { Verhoogde } \\
\text { vaginale afskeiding. } \\
\text { kleurloos. } \\
\text { nie-irriterend } \\
\text { dun of mukeus. } \\
\text { skoon of melkerig. } \\
\end{array}$ \\
\hline
\end{tabular}

\section{. Een tot een rerhouding.}

Opgedra aan in senior verpleegkundige

1.1 Vermy nylon onderklere en broekiekouse en vogtigheid by vaginale arca. Dra absorberende katoen onderklere

1.2 Badpoeier bevorder droogheid en gemak. vermy vaginale sproei en vaginale spoelings

1.3 Skep geleentheid vir die swanger vrou om te praal oor enige verandering in vaginale afskeiding en die perineale area.

$1 .+$ Neem in vaginale? servikale smeer

\section{E. Dag \\ R. Ive \\ Len tot een verhouding. \\ Opgedra aan 'n senior verpleegkundige:}

1.1 Vermy nylon onderklere en broekiekouse en vogtigheid by vaginale area. Dra absorberende katoen onderklere.

1.2 Badpoeier bevorder droogheid en gemak. vermy vaginale sproei en vaginale spoelings.

1.3 Skep geleentheid vir die swanger vrou om te praat oor enige verandering in vaginale afskeiding en die perineale area.

1.t Neem in vaginale servikale smeer

1.5 Verduidelik vaginale toilet tegniek naamlik om vagina van voor na agter skoon te maak na eliminasie.

1.6 Verduidelik die gebruik van geneesmiddel terapie soos voorge. skryf deur geneesheer. onder andere vaginale rome en vaginale tablette.

1.7 Stel die belangrikheid daarvan om koïsus te staak totdat die infeksie genees is - evalueer elke kliënt, en beveel andersins die gebruik van 'n kondoom aan.

1.8 Algehele privaatheid.

2. Monilia

2.1 Stel oorsaak vas, byvoorbeeld diabetes mellitus. antibiotika of steroid terapie.

2.2 Verkry in vaginale smeer vir ontleding

2.3 Stel vas of kliënt pyn met dispareunie ondervind

2.4 Stel lokale aanwending van K-Y jelly voor of in flou oplossing van koeksoda: I gram in $150 \mathrm{ml}$ water. dit is ' $\mathrm{n}$ $0.75 \%$ oplossing $( \pm 1$ teelepel op 3 koppies water). om die vulva mee af te spons om pruritis te verlig.

3. Trishomoniase

3.1 Motiveer kliënt om seksuele vennoot vir behandeling te bring. en verduidelik die rede.

3.2 Verduidelik dat slegs simptomatiese behandeling Ivdens die eerste trimester gegee word weens die teratogeniese effek van metronidazole (Flagyl)
10. Hipotensie Sindroom

10.1 Verduidelik oorsaak aan kliënt.

\section{Een tot een verhouding.}

Opgedra aan in renior verpleegkundige:

1.1 Vermy nylon onderkler en broekiekouse en vogtigheid by vaginale area. Dra absorberend katoen onderklere

1.2 Badpoejer bevorder droogheid en gemak. vermy vaginale sproe en vaginale spoelings

1.3 Skep geleentheid vis die swanger vrou om te praat oor enige ver. andering in vaginale afskeiding en die perineale area.

1.4 Neem in vaginale: servikale smeer
2. Monilia

2. Monilia

2.I Stel oorsaak vas, brvoorbeeld diabetes mellitus. antibiotika of steroid terapie.

2.2 Verkry in vaginale smeer vir ontleding

2.3 Stel vas of kliënt pyn met dispareunie ondervind.

2.4 Stel lokale aanwending van $\mathrm{K}-\mathrm{Y}$ jelly voor of in flou oplossing van koeksoda: 1 gram in $150 \mathrm{ml}$ water. dit is in $0.75 \%$ oplossing ( \pm 1 teelepel op 3 koppies water). om die vulva mee af te spons om pruritis te verlig.

\section{Trichomoniase}

3.1 Motiveer kliënt om seksuele vennoot vir behandeling te bring. en verduidelik die rede.

3.2 Verduidelik die gebruik van metronidazole (Flagyl) soos deur geneesheer roorgeskryf 3.3 Gee voorligting van die moontlike newe-effekte van die geneesmiddel. naamlik dat dit naarheid. hoofpyn. droë mond, diarree. en duiseligheid kan bevorder.
2.1 Stel oorsaak vas, brvoorheeld diabetes mellitus. antibiotika of steroid terapie.

2.2 Verkry in vaginale smeer vir ontleding

2.3 Stel vas of kliënt pun met dispareunic ondervind

2.+ Stel lokale aanwending van K-Y jelly voor of in flou oplossing van koeksoda: I gram in $150 \mathrm{ml}$ water. dit is in $0.75 \%$ oplossing ( \pm 1 leelepel op 3 koppies water), om dic vulva mee af te spons om pruritis te verlig.

3. Trichomoniase

3.1 Motiveer kliënt om seksuele vennoot vir behandeling te bring. en verduidelik die rede

3.2 Verduidelik dic gebruik van metronidazole (Flagyl) soos deur geneesheer woorgeshruf.

3.3 Gee voorligting van die mountlike newe-effektc van die geneesmiddel. naamlik dat dit naarheid. hoofprn. droë mond. diarree. en duiseligheid kan bevorder. 
E. dae en B. tye
Verpleegvoorskrifte Voor 16 weke
4 Gonoree

4.1 Moedig kliënt aan om kontakte te bring vir mediese behandeling en verduidelik die rede.

4.2 Gee voorligting ten opsigte van raginale higiëne: veral as daar ook kondilomata teenwoordig is.

E. dag

R. tye

3. Potensiele $p$

gevolg van:

Rugpin. spatare.

hemorroide

hardlvwigheid

Omkeerbaar

graad van rugpyn

Verminderde rugpin

graad van spatare

Aanvaar ongerief

an spalare

graad van hemorroide

graad van hardlywig- Geen hardlıwigheid heid

\section{Rugpyn}

1.1 Stel oorsaak vas en verwys na 'n geneesheer.

\section{Spatare}

2.1 in Voorkomende en rerligtingsmaatreè] is om die bene gereeld te lig. Verduidelik metodes.

2.2 Vermy lang periodes van sit of om die bene by die knieë te kruis wat drukking op die venas veroorsaak.

2.3 Vermy ook lang periodes van staan.

2.4 Lig bene hoër as kop wanneer lê.

2.5 Stel die gebruik van spataarkouse. wat daagliks vanaf opstaantwd pedra moet word, voor

2.6 Beklemtoon die belang rikheid om dié kouse daagliks met seep en water te was om hulle elastisiteit te behou.

2.7 Doen in Homantoets as klient van pron in haar been kla

2.8 Indien vulva spatare roorkom. gee voorligting om die pelvisarea saam met die hene op te lig om sodoende veneuse dreinasie te hevorder.
Verpleegroorskrifte Tussen 16-28 weke

3.4 Alkohol gebruik moet te alle tve verms word. veral met medikasie toediening.

\section{Gonore}

4.1 Moedig kliënt aan om kontakte te bring vir mediese hehandeling en verduidelik die rede.

4.2 Gee voorligting ten opsigte van vaginale higiëne: veral as daar ook kondilomata teenwoordig is.

\section{Rugpyn}

1.1 Verduidelik die oorsaak van rugpin.

1.2 Onderrig kliênt in die pelviese tilt oefening tilt die anteriot pelvis opwaarts om die kurwature van die rug ouromaties te verminder. di sal rugpin verminder.

1.3 Demonstreer die korrekte tegniek om in voorwerp van die vloer af op te lig en kontroleer insig san die kliënt in die gebruik tan die heenspiere

1.4 Gee voorligting nor werksareas wat hidra tot rugpin en stel aanpassing voor om stres op die rug te verminder (bi: werkshoogie)

1.5 Stel die gehruik san in ondersteunende gordel voor. veral bi in hangbuik (penduleuse abdomen)

1.6 Stel die dra van gelyk vormige skoenhakke voor.

\section{Spatare}

2.1 in Voorkomende en verlig tingsmaatreël is om die bene gereeld te lig. Verduidelik metodes

2.2 Vermy lang periodes van sit of om die bene by die knieë te kruis uat drukking op die venas veroorsaak.

2.3 Vermy cok lang periodes ran staan.

2.4 Lig bene hoër as kop uanneer lè.

2.5 Stel die gebruik van spataarkouse. wat daagliks vanaf opstaantvd gedra moet word. voor.

2.6 Beklemtoon die belangrikheid om die kouse daagliks met seep en water te was om hulle elastisitesi te behou.

2.7 Doen in Homantoets as kliēnt van pvin in haar heen kla.

2.8 Indien rulva spatare voorkom. gee voorligting on die pelvisarea saam met die hene op te lig om sodoende veneuse dreinasie te hevorder
Verpleegvoorskrifte tussen 28 weke en voltyd

3.4 Alkohol gebruik moet te alle tse vermy word. reral mer medikasic toediening.

4. Gonoree

4.1 Moedig kliënı aan om kontakte te bring vir mediese behandeling en verduidelik die rede.

4.2 Gee rootligting ten opsigte van vaginale higiẻne: veral as daar (no kondilomata teenwoordig is.

43 Neem in herhaal-servikale smeer.

1. Rugp?n

1.I Verduidelik dic (morsaak ran rugpin

1.2 Onderrig klient in die pelviese tilt oefening tilt die anterior pelvis opuaarts om die kurwature van dic rug outomaties te verminder. dit sal rugpin verminder.

1.3 Demonstreer die korrekte tegniek on in roorwerp van die vloer af op te lig en kontroleer insig van die kliënt in die gebruik van die beenspiere.

$1 .+$ Gee voorligting oor werksareas wat bidra tot rugpin en stel aanpassing voor om stres op die rug te verminder (bvi werkshoogte)

1.5 Stel die gebruik van n ondersteunende gordel vor. veral by in hang buik (penduleuse abdomen

1.6 Stel die dra van gelsk. vormige skoenhakike voor

2. Spatare

2.1 in Voorkomende en verligtingsmaatreel is om die hene gereeld te lig. Verduidelik metodes.

22 Vermy lang periodes san sit of om die bene hy die knieë te kruis wat drukking op die venas veroorsaak.

23 Vermy ook lang periode van staan

2.4 Lig bene hoer as kop wanneer lé.

2.5 Stel die gebruik van spataarkouse. uat daagliks rana! opstaanivd gedra moel word. voor

2.6 Beklemtoon die helangrikheid om die kouse daagliks met seep en uater te was om hulle elastisiteit te behou

2.7 Doen in Homantoets as kliënt van pron in haar been

2.8 Indien vulva spatare roorkom. gee voorlig ting om op haar st te rus om uterine druk on die pelvis renas te verlig. 
Verpleegvoorskrifte

Voor 16 weke

\section{Hemorroide}

3.1 Verduidelik aan kliënt

dat dit spatare van

die lae deel van die

rektum en anus is en

dat die vergrote

uterus drukking op die

bloedvate veroorsaak asook

in verplasing van die intestinale met die gevolg-

like probleem van

hardlywigheid en

hemorroide.

3.2 Verneem na simptome van hemorroides onder andere gejeuk, swelling. pyn sowel as hemorroidale bloeding en stel voorkomende en verligtende maatreëls voor soos in yspak. warm sitsbaddens en die aanwending van salwe en rome soos voorgeskryf deur 'n geneesheer.

3.3 Verduidelik die prosedure om die hemorroïdes terug te druk met behulp van 'n lubrikant

3.4 Beklemtoon die belangrikheid om hardlywigheid te voorkom.

4. Hardlỵwigheid

4.1 Verduidelik oorsaak van hardlywigheid aan kliënt

4.2 Stel 'n toename van vloeistofinname voor, asook genoeg growwigheid in die dieet. 'n gereelde toiletroetine. en voldoende daaglikse oefeninge.

4.3 Waarsku kliënt om geen medikasie sonder doktersvoorskrif te gebruik in die eerste trimester nie.

4. Potensiële edeem as gevolg van patalogiese siektetoestand en fisiologiese veranderinge

Omkeerbare data Graad van edeem

Area van edeem

Tyd van voorkoms

\section{E. dag 1. Patalogiese edeem \\ 1.1 Verkry urine vir mikroskopiese analise. \\ 1.2 Verduidelik die redes aan die kliënt. \\ 1.3 Skakel hipertensie en proteïenurie uit. \\ 1.4 Beveel kliën aan om ten minste twee ure bedags ook te rus. \\ 1.5 Reêl vir opname in die voorgeboorte saal vir observasie indien geneesheer dit verlang.}

2. Fisiologiese edeem

2.1 Vermy lang staan of sit.

2.2 Verduidelik die waarde van gereelde dorsiflek. sie van die voet om die sirkulasie te bevorder. veral by enkeledeem

\section{Hemorroide}

3.1 Verduidelik aan kliènt dat dit spatare van die lae deel van die rektum en anus is en dat die vergrote uterus drukking op die hloedvate veroorsaak asook in verplasing van dic intestinale met die gevolg. like probleem van hardlywigheid en hemorroide.

3.2 Verneem na simptome van hemorrö̈des onder andere gejeuk. swelling. pyn sowel as hemorroidale bloeding en stel voorkomende en verligtende maatreëls voor soos 'n yspak. warm sitsbaddens en die aanwending van salwe en rome soos voorgeskryf deur 'n geneesheer.

3.3 Verduidelik die prosedure om die hemorroides terug te druk met behulp van 'n lubrikant

3.4 Beklemtoon die belang. rikheid om hardlywigheid te voorkom.

4. Hardly wigheid

4.1 Verduidelik oorsaak van hardlywigheid aan kliënt.

4.2 Stel in toename van vloeistofinname voor. asook genoeg growwigheid in die dieet. "n gereelde toiletroetine, en voldoende daaglikse oefeninge.

4.3 Verduidelik die gebruik van medikasie aan wysings aan kliënt indien voorgeskryf deur in geneesheer

4.4 Waarsku die kliën om. deur in goeie daaglikse toiletroetine te beoefen. nie van die medikamente afhanklik te word nie.

1. Patalogiese edeem

1.1 Verkry urine vir mikroskopiese analise

1.2 Verduidelik die redes aan die kliënt.

1.3 Skakel hipertensie en proteienurie uit.

1.4 Beveel kliënt aan on ten minste twee ure bedags ook te rus.

1.5 Reềl vir opname in die voorgeboorte saal vir observasie indien geneesheer dit verlang.

2. Fisiologiese edeem

2.1 Vermy lang staan of sit.

2.2 Verduidelik die waarde van gereelde dorsillek. sie van die voet om die sirkulasie te bevorder. veral by enkeledeem
Verpleegvoorskrifte tussen 28 weke en voltyd

3. Hemorroide

3.1 Verduidelik aan klient dat dit spatare van die lae deel van die rektum en anus is en dat die vergrote uterus drukking op die bloedvate veroorsak asook in verplasing van die intestinale met die gevolg like probleem van hardlywigheid en hemorroide.

3.2 Verneem na simpiome van hemorroides onder andere gejeuk. swelling. pyn sowel as hemorroidale bloeding en stel voorkomende en verligtende maatreëls voor soos "n yspak. warm sitsbaddens en die aanwending van salwe en rome soos voor geskryf deur in geneesheer.

3.3 Verduidelik die prosedure om die hemorroides terug te druk met behulp van 'n lubrikant

3.4 Beklemtoon die belangrikheid om hardlywigheid te roorkom.

4. Hardly̧uigheid

4.1 Verduidelik oorsaak van hardlywigheid aan klient.

4.2 Stel in toename van vloeistofinname voor. asook genoeg growwigheid in die dieet. in gereelde toiletroetine. en vol doende daaglikse oefeninge.

4.3 Verduidelik die gebruik van medikasie aanwysings aan klient in dien voorgeskrvf deur in geneesheer

4.4 Waarsku die kliën om deur 'n goeie daaglikse tollet roetine te beoefen, nie van die medikamente afhanklik te word nie

1. Patalogiese edeem

1.1 Verkry urine vi mikroskopiese analise

1.2 Verduidclik die redes aan die klient.

1.3 Skakel hipertensie en proteienurie uit.

1.4 Beveel klient aan om ten minste twee ure bedags nok te rus.

1.5 Reel vir opname in die voorgeboorte saal vir observasie indien geneesheer dit verlang

2. Fisiologiese edeem

2.1 Vermy lang staan of sit

2.2 Verduidelik die waarde van gereelde dorsiflek sie van die voet om die sirkulasie te bevorder. veral by enkeledeem 
Tussentydse verwagle resultate
E. dae en $B$. tye
Verpleegvoorskrifte

Voor 16 weke

2.3 Gee voorligting om st twe rekke of bande om bene te vermy.

2.4 Tydens rusperiodes moet beide bene en heupe gehig word. Beveel rusperiodes van twee ure bedags sterk aan.

2.5 Verduidelik die verskil tussen fisiologiese edeem en patologiese edeem aan die kliënt en versoek haar on dringend mediese hulp te verkry indien sy na in nagrus ringuinger edeem het, of swelling van hande, voete, bene oe of die sakrale area (stuitjie).

\begin{tabular}{|c|c|}
\hline $\begin{array}{l}\text { 5. Potensiële } \\
\text { plasentale ontoe- } \\
\text { reikendheid as } \\
\text { gevolg van } \\
\text { wanvoeding. rook- } \\
\text { gewoontes. } \\
\text { hipertensiewe } \\
\text { toestande. nier- } \\
\text { siektes en } \\
\text { TORCH } \\
\text { (Toxoplasmosis } \\
\text { Rubella. } \\
\text { Cytomegalo virus } \\
\text { Herpes tipe 2) } \\
\text { Omkeerbare data: }\end{array}$ & $\begin{array}{l}\text { Bevredigende bewys } \\
\text { van fetale groei } \\
\text { en moederlike } \\
\text { weisyn }\end{array}$ \\
\hline Obesiteit & $\begin{array}{l}\text { normale massatoe- } \\
\text { name } 10-12 \mathrm{~kg} \text { per } \\
\text { swangerskap }\end{array}$ \\
\hline Anemie & $\begin{array}{l}\text { Hb. van } 11.5 \mathrm{~g} \% \text { of } \\
\text { meer }\end{array}$ \\
\hline Rook .......... & staak rook \\
\hline Hipertensie & $\begin{array}{l}\text { bloeddruk } \\
110 / 70-120 / 80\end{array}$ \\
\hline Proteienurie ....... & $\begin{array}{l}\text { geen eiwitte in } \\
\text { uniene }\end{array}$ \\
\hline Edeem ................ & geen edeem \\
\hline $\begin{array}{l}\text { Verminderde ..... } \\
\text { fetale beweging }\end{array}$ & $\begin{array}{l}\text { nie minder as } \\
10 \text { skoppe in } \\
24 \text { uur nie. }\end{array}$ \\
\hline
\end{tabular}

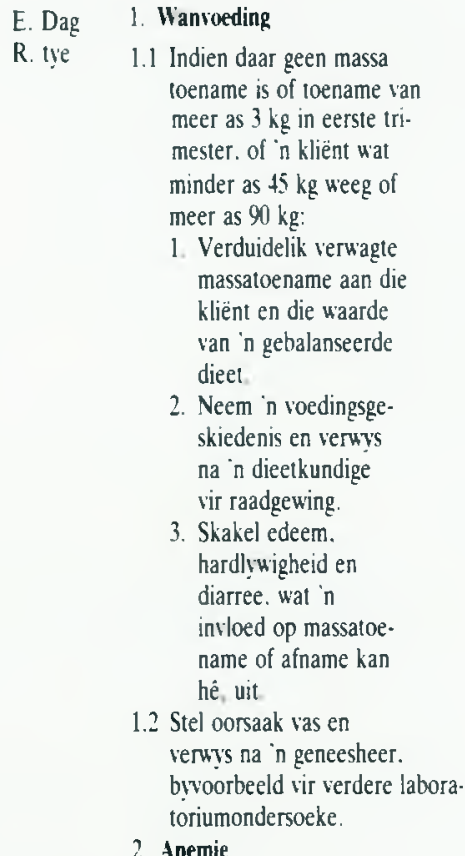

2. Anemie

2.1 Doen volbloedtelling mel opname.

3.2 Verwys na in geneesheer indien abnormale resul. tate voorkom.

2.3 Verduidelik die gebruik van ỵsterpreparate en om dit na ete te neem.

2.4 Indien kliënt nog baie naar is beveel aan dat sy wag met die tablette. en beveel 'n yster-ryke dieet aan.

3. Hipertensie, proteienurie

3.1 Doen 'n mikroskopiese ontleding van uriene en veruy's na in geneesheer.

3.2 Vewys na in geneesheer indien bloeddruk na in rusperiode hoër as 140,90 is

3.3 Beveel ekstra rusperiodes aan. Twee ure bedags en $8-10$ ure snags.

3.4 Neem die bloeddruk teruyl kliënt op sy le of sit.
Verpleegvoorskrifte

Tussen 16-28 weke

2.3 Gee voorligting om strwe rekke of bande on bene te vermy

2.4 Tydens rusperiodes moet beide bene en heupe ge lig word. Beveel rusperiodes van twee ure bedags sterk aan

2.5 Verduidelik die verskil tussen fisiologiese edeem en patologiese edeem aan die kliënt en versoek haar om dringend mediese hulp te verkry indien sy na $n$ nagrus ringvinger edeem het. of sweelling van hande, roete, bene oë of die sakrale area (stuitjie).

1. Wanvoeding

1.1 Indien massatoename meer as $5 \mathrm{~kg}$. in dic tweede trimester is of 'n kliënt wat minder as $45 \mathrm{~kg}$. weeg of meer as $90 \mathrm{~kg}$.

1. Verduidelik verwagte massatoename aan die kliënt en die waarde van in gebalanseerde dieet.

2. Neem in roedingsgeskiedenis en veru's na ' $n$ dieetkundige vir raadgewing.

3. Skakel edeem. hardlswigheid en diarree. wat in invloed op massatoe name of afname kan hè. uit

1.2 Stel oorsaak vas en verwy's na 'n geneesheer. byvoorbeeld vir verdere laboratonimondersoeke.

2. Anemie

2.1 Herhaal Hb. op 28 weke of doen in volbloedtelling me opname.

2.2 Verwus na in geneesheer indien $\mathrm{Hb}$. minde as $11.5 \mathrm{mg}$ is.

2.3 Verduidelik die ge bruik van ysierpreparate en om dit na ete te neem.

2.4 Indien vordering op terapie nie bevredigend is nie. kontroleer met in rektale ondersoek indien klièn sé ș neem die medikamente (Swart stoelgang) of remeem na kleur van stoelgang.

2.5 Beveel in ssterrvke dieet aan.

3. Hipertensie, proteienurie

3.1 Doen in mikroskopiese ontleding van uriene en verwiss na in gences. heer

3.2 Veruys na in geneesheer indien bloeddruk na rusperiode op linker sy hoër as $140: 90$ is.
Verpleegvoorskrifte tussen 28 weke en roltyd

2.3 Gee voorligting om stiwe rekke of bande om bene te verms.

2.t Tydens rusperiodes moel beide bene en heupe gelig word. Beveel rus periodes van twee ure hedags sterk aan.

2.5 Verduidelik die verskil tussen fisiologiese edeem en patologiese edeem aan die klient en versoek has om dringend mediese hulp te verkry indien sy na n nagrus ringsinger edeem her. of suelling van hande. voete. hene oe of die sakrale area (stuitjie).

1. Wanvoeding

1.1 Indien massatoename meer as $5 \mathrm{~kg}$. in die derde trimester is, of in kliënl wat minder as $45 \mathrm{~kg}$. weeg of meer as $90 \mathrm{~kg}$.

1. Verduidelik verwagte massatoename aan die klient en die saarde ran in gebalanseerde dieet.

2. Neem in roedingsge skiedenis en veruvs na "n dieetkundige vir raadgewing.

3. Skakel edeem. hardlswigheid en diarree. Hat in invloed op massatoename of afname kan hẻ. uit

1.2 Stel oorsaak vas en verw's na in geneesheer bywoorbeeld vir verdere laboratoriumondersoeke

2 Anemi

2.1 Herhaal Hb. op 36 weke swangerskap of rolbloed telling met opname.

2.2 Veruis na in geneeshee indien $\mathrm{Hb}$. minder as $11.5 \mathrm{mg}$

33 Verduidelik die gebruik van ysterpreparate en om dit na ete te neem.

2.4 Bloedoortapping.

3. Hipertensie. Proteien urie, Eisitte

3.1 Doen in mikroskopiese ontleding van uriene en veruis na in geneesheer.

3.2 Veruys na in geneesheer indien bloeddruk na rusperiode op linker sy hoer as 14090 is.

3.3 Beveel ekstra rus periodes aan. Twee ure bedags en 8-10 ure snags.

3 . Neem die bloeddruk ter uỵl kliënt op sy lé of

3.5 Indien pre-eklampsie gediagnoseer word. gebruik sorgplan vir pre. eklampsie. 
Verpleegvoorskrifte

Tussen 16-28 weke

3.3 Beveel ekstra rusperoodes aan. Twee ure bedags en 8-10) ure snags.

3.t Neem die bloeddruk terwyl klient op sy lé of sit.

4. Rook

4.1 Een tot een verhouding opgedra aan

4.2 Verduidelik die nadelige effek van niko. tien tydens swangerskap en na geboorte op borsvoeding.

4.3 Beplan saam met haar hoe om rook af te leer of dit summier te

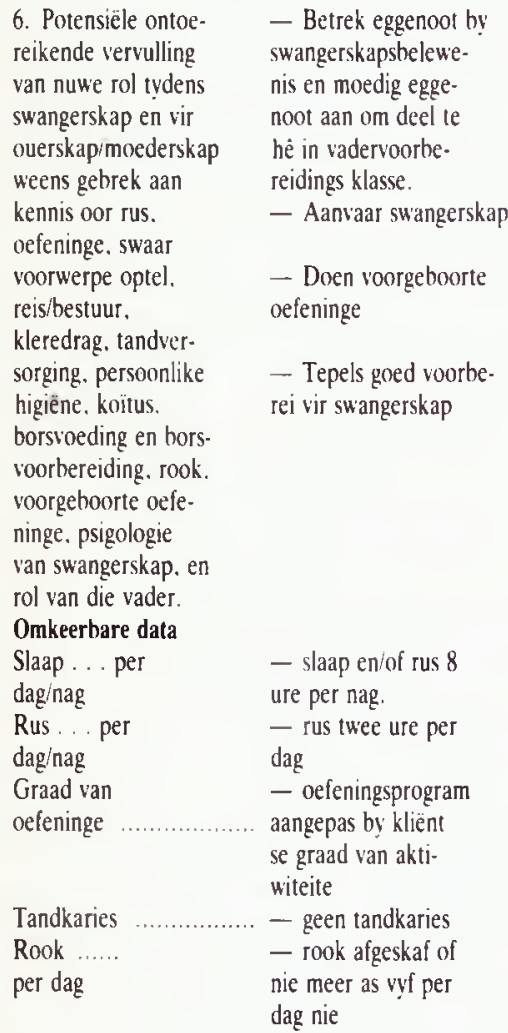

\section{staak.}

Rus en slaap

1.1 Verduidelik die oor. saak van moegheid, naamlik verhoogde progesteroonvlakke in die bloed wat in natururlike sedeermiddel is. en mikturisie.

1.2 Moedig agt ure slaap aan en neem individuele behoefte in ag.

1.2.1 Sorg vir genoeg vars lug in kamer. dit voorkom neusverstopping.

1.3 Moedig twee ure rus per dag aan en werk in realistiese plan uit vir werkende swanger vroue, en dié met klein kindertjies tuis.

1.4 Moet nie berie kruis wanneer op in stoel sit nic. dit be. lemer bloedstoevoer.

1.5 Vermy slaappille

\section{Oefeninge}

2.1 Stel die helang dat dit nie die tyd is om met in nuwe uitputtende sportaktiwiteit te hegin nie

2.2 Gaan roort met bestaande aktiwiteite maar voorkom uitputting en verskaf voorligting:

2.2.1 Stap: is goed en heilsaam. moedig aan om daagliks te stap.

2.2.2 Swem: vermy hoogduik. en swemduik.

2.2.3 Dans: Vermy akrobaticse danse

2.2.4 Fietsry: hou geen nadele in nit. Verduidelik dat reflekse afneem en kliënı makliker 'n ongeluk kan maak.

2.2.5 Perdry: verduidelik die gevaar van 'n aborsie as kliën van in perd afval. balans kan ook versteur wees.

\section{Rook}

4.1 Een tot cen verhouding opgedra aan

4.2 Verduidelik die nadelige effek van nikotien tydens geboortc op borsvoeding.

4.3 Beplan saam met haar hoe om rook af te leer of dil summier te staak.

1. Rus en slaap

1.1 Stel oorsaak (bywoorbeeld anemie) vas indien kliënt baie moeg is en net wil slaap en verwys na geneesheer

\subsection{Moedig agt ure} slaap aan en neem individuele behoefte in ag.

1.3 Moedig twee ure rus per dag aan en werk $n$ realistiese plan uit vir werkende swanger vroue. en dié met klein kindertjies tuis.

1.4 Moet nie die bene kruis wanneer op in stoel sit nie. dit belemmer bloedstoevoer.

1.5 Ontmoedig die gebruik van slaappille en leer kliênt ontspanningsoefeninge.

\section{Oefeninge}

2.1 Stel die belang dat dit nie die twd is on met in nuwe uitputtende sportaktiwiteit te begin nie.

2.2 Gaan voort met bestaande aktiwiteite maar roorkom uitputting en verskaf voorligting:

2.2.1 Stap: is goed en heilsaam. moedig aan om daagliks te stap.

2.2.2 Swem: verms hoog. duik en swemduik.

2.2.3 Dans: vermy akroha tiese danso

2.2. 4 Perdry: verduidelik die gevaar van 'n aborsic as kliënt van 'n perd afval. balans kan $00 k$ versteur wees.

2.2 .5 Waterski: verduidelik dat dit nie vir heginners raadsaam is nie.
Verpleegvoorskrifte tussen 28 weke en voltyd
4. Rook

4.I Een tot cen verhouding opgedra aan

4.2 Verduidelik die nadeligo effek van nikotien tydens swangerskap en na geboorte op horsvoe ding.

4.3 Beplan saam met haar hoe om rook af tc leer of dit summier te staak

1. Rus en slaap

1.I Verduidelik die oorsaak van slaapprobleme. soos die vergrote abdomen. verhoogde mikturisie en aktiwitejte van die fetus

1.2 Moedig kliënt alan om in Sims posisic te ontspan of om op har linker sy teen ekstra kussings te slaap.

1.3. Moedig twee use rus per dag aan en werk ' $n$ realistiese plan uit vis werkende swanger vroue. en die met klein kindertjies tuis.

1.4 Moet nie die bene kruis wanneer op 'n stocl sit nie. dit belemmer bloedstoevoer.

1.5 Vermy slaappille.

1.6 Moedig 'n warm drankie in uur voor slaaptrd aan.

1.7 Verduidelik sckere onlspanningstegnicke aan klient en verwss na voorgeboorte oefeningc en of voorbereidingsklasse.

2. Oefeninge

2. I Stel die helang dat dit nie die tod is om met in nuwe uitputtende sportaktiwiteit te hegin nic

2.2 Gaan vnort met bestaande aktiwiteitc maar voorkom uilputting en verskaf voorligting

2.2.I Stap: is goed en heil saam. moedig aan om dagaliks te stap.

2.2.2 Srem: vermy hongduik. en swemuluik

2.2.3 Dans: vermı akrobatiese danse.

2.2. Perdry: verduidelik die gevaar van in aborsic as kliënt van in perd afsal. balans kan ook verstcur wees.

2.2.5 Waterski: verduidelik dat dit nie vir beginners raadsaam is nie. 
Verpleegroorskrifte

Voor 16 weke

2.2.6 Waterski: verduidelik dat dit nie vir beginners raadsaam is nie

2.3 Optel van swaar voorwerpe:

Verduidelik rede waarom dit liefs vermy moet word. Demonstreer korrekte tegniek om in voorwerp op te tel. Hurk om stremming te voorkom: ook as sy in klein kindjie moe optel. Kniel voor kinders om hulle te troos.

3. Reis: Ontmoedig afstande langer as $160 \mathrm{~km}$ en om langer as twee ure aaneen te $r y$

3.1 Vermy 'n vliegtuig wat nie drukvas is nje.

3.2 Vermy reispille en raadpleeg geneeshee

3.3 Vermy reis tydens vaginale bloeding en kontak gegeneesheer

3.4 Met langer ritte moet kliënt na twee ure vir "n halfuur rondbeweeg voor sy die rit voortsit.

4. Kleredrag: Ontmoedig stvwe klere, veral rekke wat die bloedstoevoer belemmer en tot spatare lei.

4.1 Verduidelik aan die kliênt en beplan saam met haar ' $n$ realistiese uitrusting. neem klimaat, seisoen en verwagte datum by beplanning in ag.

4.2 Skoene: Moedig dieselfde hoogte hakke en voetoefeninge

4.3 Kouse: Ontmoedig die dra van kouse, behalue by spatare.

4.4 Buustelyfie: Verduidelik die waarde van 'n goedondersteunde bra met bre bande oor skouers. Elastiese bande kan later uitrek.

4.5 Stel kliënt bekend aan die spesiale voorgeboorte bra s wat vir die groter wordende borste voorsiening maak.

4.6 Onderklere: Ontmoedig stywe onderklere, dit is ongemaklik en lei tot sweet in inguinale area.

4.7 Moedig die dra van katoen of wegdoenbare broekies aan waar oormatige vaginale afskeiding voorkom.
3. Reis: Ontmoedig afstande langer as $160 \mathrm{~km}$ en om langer as twee ure aaneen te ry

Verpleegvoorskrifte

Tussen 16-28 weke

2.3 Optel van swaar voor-

werpe: verduidelik waarom dit

liefs vermy moet word.

Demonstreer korrekte

tegniek om in voorw'erp op te tel. Hurk om stremming te voorkom:

ook as sy in klein kindjie moet optel. Kniel voor kinders om

hulle te troos.

1 Vermy 'n vliegtuig wat nie drukvas is nie.

3.2 Raadpleeg geneesheer vir reispille.

3.3 Vermy reis tydens vaginale bloeding en kontak geneesheer.

3.4 Met langer ritte moet kliënt na twee ure vir "n halfuur rondbeweeg voor sy die rit voortsit.

4. Kleredrag: Ontmoedig stywe klere. veral rekke wat die bloedstoevoer belemmer en tot spatare lei

4.1 Verduidelik aan die kliênt en beplán saam meı haa in realistiese uitn'sting. neem klimaat. seisoen en verwagte datum by beplanning in ag

4.2 Skoene: Moedig dieselfde hoogte hakke en voetoefeninge aan

4.3 Kouse: Ontmoedig die dra van kouse. behalwe by spatare.

4.4 Buustelyfie: Verduidelik die waarde van in goedondersteunde bra met breë bande oor skouers. Elas tiese bande kan later uitrek.

4.5 Stel kliënt bekend aan die spesialc voorgeboorte bra's wat vir die groter wordende borste voorsiening maak

4.6 Onderklere: Ontmoedig strwe onderklere. dit is ongemak lik en lei tot sweet in in inguinale area.

4.7 Moedig die dra van $k$ loen of wegdoenbare broekies aan waar oormatige vaginale afskeiding voorkom
Verpleegvoorskrifte tussen

28 weke en voliyd

2.3 Optel van swaar voorwerpe Verduidelik rede warom di liefs vermy moet word Demonstreer korrekte tegniek om in voorwerp op te tel. Hurk om stremming te voorkom; ook as sy in klein kindjie moet optel. Kniel voor kinders om hulle te troos.

3. Reis: Ontmoedig afstande langer as $160 \mathrm{~km}$ en on langer as twee ure aaneen te

3.1 Vermy 'n vliegtuig wat nie drukvas is nie.

$3.2 \mathrm{Na} 30$ weke is in doktersertifikaat nodig om op in vliegtuig te ry.

3.3 Raadpleeg in geneesheer vir reispille.

3.4 Vermy reis tydens enige vaginale bloeding en kontak geneesheer

3.5 Vermy reis wat nie dringend noodsaaklik is nie. veral in die laaste ses weke van swangerskap.

4. Kleredrag: Ontmoedig sitwe klere. veral rekke wat die bloedstoevoer belemmer en tor spatare lei.

4.1 Verduidelik aan die klien en beplan saam met haar in realistiese uitrusting. neem klimaat. seisoen en verwagte datum by beplanning in ag.

4.2 Skoene: Moedig dieselfde hoogte hakke en voetoefeninge aan

4.3 Kouse: Ontmoedig die dra van kouse. behalwe by spatare

4.4 Buustelvfie: Verduidelik die waarde van in goed ondersieunde bra mer breè bande oor skouers. Elas. tiese bande kan later uitrek.
+5 Stel kliënt bekend aan die spesiale voorgeboorte bra's wat vir die groter wordende borste voorsiening maak.

4.6 Verduidelik die grootte van voedingsbra"s en stel voor dat die klient vir eers net een koop. naamlik as sy in $36 \mathrm{C}$ gedra het. sal sy w'aarskynlik na die ge boorte in 38A of $38 \mathrm{~B}$ dra

4.7 Onderklere: Ontmoedig stywe onderklere. dit is ongemaklik en lej tot sweet in ' $n$ inguinale area.

4.8 Moedig die dra van katoen of wegdoenbare broekies aan waar oormatige vagjnale arskeiding loorkom. 
5. Tandversorging: Verduidelik die noodsaaklikheid om ' $n$ tandarts te be besoek en dat die kliënt vir die tandarts moet sê dat sy swanger is

5.1 Wys die kliënt op die voe dingswaarde van melk, maa die noodsaaklikheid om kilojoules te beperk waar massaprobleme ondervind word. Verwys na 'n geneesheer vir kalsium-tablette.

5.2 Moedig die gebruik van 'n tandepasta met 'n hoë kalsiuminhoud aan by tandkariës en verwys na 'n tandarts.

5.3 Moedig die gebruik van 'n tandepasta spesifiek vir sensitiewe tandvleise aan en die gebruik van 'n sagte tandeborsel.

5.4 Verduidelik die waarde van die korrekte tegniek om tande te borsel.

\section{Persoonlike higiëne}

6.1 Bad: Waarsku kliënt da water nie te warm moe wees nie - weens die gevaar van floute

6.1.1 Moedig die gebruik van in badmatjie aan om te voorkom dat sy in die bad gly.

6.2 Hare en naelversoring: Verduidelik die rede vir naels wat bros is en skeur.

6.2.1 Verneem na die dieet wat kliënt volg en verskaf voorligting

6.2.2 Moedig die dra van naellak en handskoene aan

6.2.3 Verduidelik die waarde van handmassering.

6.3 Buikversorging: Moedig in lanoliensmeer vi die gejeuk van die buik weens die veluitset aan.

6.3.1 Gee voorligting oor wanneer kliēnt lewe kan verwag en om terug te rapporteer

6.4 Borsvoeding: Vermy die gebruik van seep by tepels indien die kliënt gaan bors voed. omdat dit die tepels kan laat kraak.

6.4.1 Moedig die gebruik van van in wateroplosbare salf (umgentum aquosum emulsificans) aan.

6.4.2 Maak tepel na bad met growwe handdoek droog. maar die vryf moet nie die tepel irriteer of seermaak nie.

6.4.3 Verduidelik en demonstreer die tegniek om die tepel vir in kort rukkie elke dag te rol.
5. Tandversorging: Verduidelik die noodsaaklikheid om 'n tandarts te besoek en dat die kliënt vir die tandarts moet sê dat sy swanger is.

5.1 Wys die kliënt op die voedingswaarde van melk. maar die noodsaak likheid om kilojoules te beperk waar massaprobleme ondervind word. Verwys na 'n geneesheer vir kalsium tablette.

5.2 Moedig die gebruik van in tandepasta met hoë kalsiuminhoud aan by tandkariës en verwys na 'n tandarts

5.3 Moedig die gebruik van 'n tandepasta spesi fiek vir sensitiewe tandvleise aan en die gebruik van 'n sagte tandeborsel.

5.4 Verduidelik die waarde van die kor rekte tegniek om tande te borsel

\section{Persoonlike higiëne}

6.1 Bad: Waarsku kliënt dat water nie te warm moet wees nie - weens die gevaar van floute.

6.1.1 Moedig die gebruik van in badmatjie aan om te voorkom dat sy in die bad glv.

6.2 Hare en naelversorging:Verduidelik die rede vir naels wat bros is en skeur.

6.2.1 Verneem na die dieet wat klient volg en verskaf voorligting.

6.2.2. Moedig die dra van naellak en hand skoene aan

6.2.3 Verduidelik die waarde van handmassering.

6.3 Buikversorging: Moedig n lanoliensmeer vir die gejeuk van die buik weens die vel uitset aan.

6.3.1 Verduidelik die belang om te let op die datum wat kliënt vir die eerste keer lewe voel. en vra haar om dit terug te rapporteer.

6.3.2 Verduidelik wat Braxton Higgs kontraksies is.

6.4 Borswoeding: Vermy die gebruik van seep by tepels indien die kliër gaan borsvoed: omdat dit die tepels kan laat kraak.

6.4.1 Moedig die gebruik van in waterop. losbare salf (umgentum aquosum emul sificans) aan.
5. Tandrersorging: Verduide lik die noodsaaklikheid om 'n tandarts te besoek en dat die kliènt vir die tandarts moet sê dat sy swanger is

5.1 Wys die klient op die voedingswaarde van melk. maar die noodsaaklikheid om kilojoules te beperk. waar massaprobleme ondervind word. Verwys na in geneesheer vir kalsiumtablette.

5.2 Moedig die gebruik van in tandepasta met hoể kalsiuminhoud aan by landkariës en verwys na in tandarts.

5.3 Moedig die gebruik van 'n tandepasta spesifiek vir sensitiewe tandvleise aan en die gebruik van in sagte tandeborsel.

5.4 Verduidelik die waarde van die korrekte tegniek om tande te borsel.

\section{Persoonlike higiëne}

6.1 Bad: Waarsku die kliënt dat water nie te warm moet wees nie - weens die gevaar van floute.

6.1.1 Moedig die gebruik van in badmatjie aan om te voorkom dat sy in die bad gly.

6.2 Hare en naelversorging: Verduidelik die rede vir naels wat bros is en skeur.

6.2.1 Verneem na die dieet wat kliënt volg en verskaf voorligting.

6.2.2 Moedig die dra van naellak en handskoene aan

6.2.3 Verduidelik die waarde van handmassering.

6.3 Buikversorging: Moedig in lanoliensmeer vir dic gejeuk van die buik weens die veluitset aan.

6.3.1 Verduidelik die belang om te let op die datum wat klient vir die eerste keer lewe voel en ura haar om di terug te rapportee

6.3.2 Verduidelik aan die kliënt wa Braxton Higgs kontraksies is en dat van die kontraksies soms baie sterk sal wees en dat uitputting vermy moet word.

6.t Borsvoeding: Vermy dic gebruik van seep by die tepels indien klient gaan borsvoed: omdat dit die tepels kan laat kraak.

6.4.1 Moedig die gebruik van in wateroplosbare salf (umgentum aquosum emulsificans) aan. 
E. dae en $B$. tye
Verpleegvoorskrifte

Voor 16 w'eke

6.4.4 Kontroleer vir inversie van die tepel. Gee in tepeldop om te dra en verduidelik hoe dit gedra moet word.

6.4.5 Orale stimulasie van die tepel kan aanbeveel word indien dit deel van die liefdespel by die egparar is

6.4.6 Indien bogenoemde tegnieke nie help nie. laat die geneesheer die tepel met suigdruk in die hospitaal of spreekkamer uittrek.

6.4.7 Verduidelik die waarde van sonlig op die tepels.

6.4.8 Moedig die aanwending van suiwer lanolien aan die tepels aan.

7. Koitus: Verduidelik dat dit normaal is dat sy "n afname in libido $k$ an ervaar in die eerste trimester van swangerskap. Kilheid is slegs trdelik.

7.1 Vrou moet sagkens behande word. borste is teer.

7.2 Verduidelik die noodsaak likheid om koïtus te ver$\mathrm{mr}$ indien in vaginale bloeding of ' $n$ dreigende miskraam sou begin.

Rook: Een tot een verhouding. Opgedra aan. .

8.1 Verduidelik die gevaar en effek van nikotien op die swangerskap.

8.2 Werk in plan van aksie saam met die kliënt uit on rook geleidelik te staak of nie meer as 5 per dag te rook nie. of summier te staak.

9. Borswoeding: Moedig die kliënt aan om te borstoed

9.1 Verduidelik die voordele van borswoeding

9.2 Gee voorligting vir borsroeding (sien 6.4).
Verpleegvoorskrifte

Tussen 16-28 weke

6.4.2 Maak tepel na

bad met growwe hand-

doek droog. maar die vrif moet nie die tepel irriteer of seer-

maak nie

6.4.3 Verduidelik en demonsireer die tegniek om die tepel

vir 'n kort rukkie elke dag te rol.

6.4.4 Kontsoleer vir inversie van die tepel. Gee in tepeldop om te dra en verduidelik hoe dit gedra moet word.

6.4 .5 Orale stimulasie van die tepel kan aanbereel word indien dit dee ran die liefdespel b die egparar is

6.4.6 Indien bogenoemde tegniek nie help nie laat die genees heer die tepel met suigdruk in die hospitaal of spreek kamer, uittrek.

6.4.7 Verduidelik die waarde van sonlig op die tepels.

7. Koitus: Verduidelik dat die libido gewoonlik in die lreede irimester verbeter en indien kilheid roorkom is dit tydelik

7.1 Vrou moet sagkens behandel word. borste is teer.

7.2 Verduidelik die nood saaklikheid om koitus te vermy indien 'n vaginale bloeding of ' $n$ dreigende miskraam sou begin.

7.3 Tegniek kan en moel selfs verander word weens die vergrote buik

8. Rook: Een tot een ver houding: Opgedra aan

8.1 Verduidelik die gevaa en effek van nikotien op die swangerskap.

8.2 Werk in plan san aksie saam met die kliënt uit om rook geleidelik te staak of nie meer as 5 per dag te rook nie. of summier te staa.

9. Borsroeding: Moedig die kliënt aan om te borsroed.

9.1 Verduidelik die voordele van borswoeding

9.2 Gee voorligting vir borsroeding (sien 6.4).

9.3 Kontroleer die tepel se toestand

9.4 Indien die tepel begin lek moedig die dra van tussenvoedingdoekies (of in sanitêre doekie w'a in drie dele verdeel is - meer ekonomies) aan. Beklemtoon dat tepel en bors droog moet bly
Verpleegioorskrifte tussen

28 weke en roltrd

6.4.2. Maak lípel na bad met 'n growwe handdoek droog mas die srvf mos nie die tepel irriteer of seermaak nie.

6.4.3 Verduidelik en demonstreer die tegniek om die tepel vir "n kort rukkie elke dag te rol.

6.4.4 Kontroleer vir inversie van die tepel. Gee "n tepeldop on te dra en verduidelik hoe dit gedra moet word.

6.4.5 Orale stimulasie van die tepel kan aanbeveel word indien dit deel van die liefdespel b dic egpaar is

6.4.6 Indien bogenoemde tegnieke nic help nie laat die geneesheer dic tepel mel suigdruk in die hospitaal of spreekkamer, uittrel

6.4.7 Verduidelik die warde ran sonlig op die lepels.

6.4.8 Moedig die aanwending van suiker lanolicn aan die tepels aan

7. Koitus: Verduidelik dat die libido gewoonlik ver. beter in die derde irimester en indien kilheid roorkom is dit trdelik.

7.1 Vrou moet sagkens behandel word. borste is lee

7.2 Verduidelik die noodsaaklikheid on koitus te ver$m s$ indien in raginale bloeding of in dreigende miskraam sou begin.

7.3 Waarsku klient on nie te lank op haar rug te lé nie keens die gevaar van hipotensie sindroom

8. Rook: Een to een verhouding: Opgedra aan

8.1 Verduidelik die gevaar en effek van nikotien op die suangerskap.

8.2 Werk in plan van aksie saam met die kliënt uit om rook geleidelik te staak of nie meer as 5 per dag te rook nie. of summier te staak.

9. Borsroeding: Moedig die kliënt aan om te borsvoed.

9.1 Verduidelik die voordele van thorswoeding.

9.2 Gee voorligting vir horsroeding (sien 6.4).

9.3 Kontroleer die tepel se toestand

9.4 Indien die tepel hegin lek moedig die dra van ussenvoedingdoekies fof sanitère doekie wal in drie dele verdeel is meer ekonomies) aan. Beklemtoon dat tepel en bors droog moet bly

9.5 Moedig kliënt aan om te begin uitmelk op plus omtrent I minuut per das en vermeerder geleidelik tol 8-10 minute op voltwd.

9.6 Demonstreer korrekte tegniek om kneusing te voorkom. 


\section{Voorgeboorte oefeninge}

Verduidelik die doel en waarde van voorgeboorte oefeninge en raai kliënt aan om te wag tot op omtrent

14 weke wanneer die ergste naarheid en moegheid afneem, voordat sy aktief met die oefeninge begin

\section{Psigologie van swangerskap}

11.1 Verduidelik dat dit normaal is om gemoeds- en gedragsafwykings te ervaar in die eerste trimester weens die skielike hormoon. verandering na bevrugting.

11.2 Verduidelik dat dit normaal is om nie nou op die baba nie. maar eerde op die swangerskap. te konsentreer

11.3 Verduidelik die gedrag van die vrou aan die eggenoot en die behoefte om geliefd en geliefkoos en en selfs vertroete! te word. in Swanger vrou kan tranerig voel sonder rede of vir die geringste rede.
10. Voorgeboorte oefeninge

Verduidelik die doel en waarde van voorgeboorte-oefeninge en moedig kliënt aan om met 'n oefenprogram te begin.

10.1 Indien die kliënt nie saam met 'n groep oefeninge kan doen nie. verduidelik kortliks 'n program waarin tegnieke van ontspanning. korrek. te asemhaling en spierversterkingsoefeninge gedemonstreer word. Moedig haar aan om dit tuis te oefen.

\section{Psigologie van swangerskap}

11.1 Indien die kliënt die realiteit van swangerskap verwerp, stel die oorsaak vas en verwys na 'n geneesheer vir konsultasie.

11.2 Indien angs en depres sie voorkom in vroue me 'n vorige gesiedenis van gekompliseerde swangerskap. stel kliënt gerus en hou haar op hoogte van die vordering van haar swangerskap.

11.3 Verduidelik die gedrag van die vrou aan die eggenoot en haar behoefte om geliefd en geliefkoos en selfs vertroe tel te word. 'n Swanger vrou kan tranerig voel sonder rede of vir die geringste rede

\section{Voorgeboorte oefeninge}

Verduidelik die doel en waarde van voorgeboorte oefeninge en moedig die

kliënt aan om met 'n oefenprogram te begin.

10.1 Indien die kliënt nie saam met 'n groep oe feninge kan doen nie, verdui. delik kortliks 'n program waarin tegnieke van ontspanning. korrekte asem haling en spierverster kingsoefeninge gedemonstreer word. Moedig haar aan om dit tuis ie oefen.

10.2 Indien 10.1 van toepassing is verduidelik an die kliënt die baringsproses en gekontroleerde asemhalingstegniek.

10.3 Indien kliënt daaroor navraag doen verduidelik die Read. Lamaze en Bradley metodes en hipnose, asook die hospitaal se beleid in hoeverre aan haar behoeftes voorsien kan word.

\section{Psigologie van swangerskap}

11.1 Indien die kliënt nie die realiteit van swangerskap aanvaar nie. stel oorsaak vas en verwys na in geneesheer vir konsultasie.

11.2 Indien angs en depressie voorkom in vroue mel vorige geskiedenis van gekompliseerde swangerskap. stel kliënt gerus en hou haar op hoogte van die vordering van haar swangerskap 11.3 Verduidelik die gedrag van die vrou aan die eg genoot en die behoefte om geliefd en geliefkoos selfs vertroetel te word. 'n Swanger vrou kan tranerig voel sonder rede of vir die geringste rede

11.4 Indien angs in die vorm van slapeloosheid voorkom ste vas of die kliënt nie vrees vir die bevalling of vir die gesondheid van die kindjie het nie. en stel gerus.

11.5 Betrek eggenoot om emo sionele steun aan die kliënt te gee.

11.6 Indien die eggenool swak in haar behoeftes voorsien selfs onvolwasse is, stel die kliënt gerus en op haa gemak. Verwys na maatskapli diens indien nodig. 


\section{$12 \mathrm{Rol}$ van $\mathrm{Pa}$}

12.1 Stel die kliënt bekend aan die fasiliteite/klasse wat beskikbaar is vir voorbereiding vir vaderskap.

12.2 Verduidelik aan die kliënt die belangrikheid om die vader by

haar swangerskapsbelewenis te betrek

12.3 Verduidelik die psigologiese reaksie van swangerskap aan die pa (sien 11.3)

\section{Rol $\operatorname{ran} \mathbf{P a}$}

12.1 Stel die kliënt bekend aan die fasilj. teiteiklasse wat beskik baar is om eggenoo vir vaderskap voor te berei.

12.2 Verduidelik aan die kliënt die belangrikheid om die vader by haar swanger skapsbelewenis te betrek.

12.3 Verduidelik die psigologiese reaksie van swangerskap aan die pa (sien 11.3).
28 weke en roltyd

12. Rol van $\mathrm{Pa}$

12.1 Stel die kliënt bekend aan die fasiliteite

klasse wat beskikbaar is om eggenoot

vir vaderskap voor te berei.

12.2 Verduidelik aan die kliënt die belangrikheid om die vader by haar swangerskiapsbelewenis te hetrek.

12.3 Verduidelik die begrip bsnding met die baba en die rol wat die pa speel.

12.4 Betrek die eggenoot om emosionele steun aan die swanger vrou te gee.

12.5 Indien die eggenoot swak in haar behoeftes voorsien en selfs onvol. wasse is, verwys na maatskaplike diens.

\section{ERRATA}

These errata concern the article "The South African Nursing Association - Quo Vadis" by $\mathrm{MC}$ van Huyssteen which appeared in Curationis Vol 7 No 3 (September 1984) pp 4-10.

The last paragraph of the first column on $p$ 9 should read - a national nursing research fund was established and nurses were invited to donate to this fund as individuals or as groups.

The continuation of the bibliography, omitted on p. 22 is as follows:

24. Searle, C. (1982). The evolution of a profession. Curationis. Vol. 5. No. 2 September 1982

25. Spier, A. (1983). Syncom Report III March (unpublished)

26. S.A. Nursing Association Documents

(a) Central Board Minutes

(i) October 1983

(ii) March 1984 (b) Executive Committee Minutes

(i) June 1983

(ii) June 1984

(c) Memoranda

(i) Memorandum aan Sy Edele die Minister van Gesondheid en Welsyn van die Sentrale Bestuur van die SAVV insake die implikasies van die verpleegdienste van die RSA voortspruitend uit die verslag van die Wetenskapskomitee van die Presidentsraad oor Demografiese Tendense in S.A. Mei 1983

(ii) Memorandum aan die komitee van ondersoek na moontlike verdere fasiliteite vir geneeskundige en tand. heelkundige opleiding. Julie 1984

(iii) Memorandum van die SAVV aan die Parlementêre Gekose Komitee oor Pensioenvoordele. Junie 1984

(iv) Memorandum on aspects of the system of nursing education and on sections of the main reports of the Commission of Inquiry into Univer- sities and the relevance thereof for nursing education. 1975

(d) South African Nursing Association Constitution

(e) Reports

(i) Report by the President of SANA on the activities of the Central Board and the Regions of the Association - 1982

(ii) Reports from Regions to the Central Board. March 1984

27. The Nursing Act 1978. (Act No. 50, 1978) as amended.

28. Thompson, R.A.E. (1983). Achieving professionalism. Curationis. Vol. 6. No. 3. September

29. Van Huyssteen, M.C. (1982). 'n EvaIuering van die opleiding van verpleeg. kundiges vir basiese registrasie in die $R S A$. D. Cur. Proefskrif. Univ. van Pretoria.

30. Wessels, P.M. (1975). 'n Oorsig van vyfen-twintig jaar opleiding van verpleeg. sters aan die Universireit van Pretoria 1949-1974. M. Cur. Univ. Pretoria.

\section{INTEKENVORM}

\section{CURATIONIS - DIE SUID-AFRIKAANSE TYDSKRIF VIR VERPLEEGKUNDE Die kwartaallikse tydskrif vir professionele verpleeglui}

Ek wil graag inteken op Curationis vir:

$\square$ een jaar $(R 10,00) \quad \square$ twee jaar $(R 18.00)$

en sluit die intekengeld van $R$.................. in.

Van en volle voorname

Adres 